\title{
Characterization of Xanthomonas hortorum pv. pelargonii Isolated from Geranium in Serbia
}

\begin{abstract}
Jelica Balaž, Faculty of Agriculture, University of Novi Sad, Novi Sad, Serbia; Žarko Ivanović, Institute for Plant Protection and Environment, Belgrade, Serbia; Andrej Davidović, Urban Public Enterprise "Gradsko Zelenilo", Novi Sad, Serbia; Renata Iličić, Faculty of Agriculture, University of Novi Sad; Jaap Janse, Dutch General Inspection Service (NAK), Department of Laboratory Methods and Diagnostics, Emmeloord, The Netherlands; and Tatjana Popović, Institute for Plant Protection and Environment, Belgrade
\end{abstract}

\begin{abstract}
Balaž, J., Ivanović, Ž., Davidović, A., Iličić, R., Janse, J., and Popović, T. 2016. Characterization of Xanthomonas hortorum pv. pelargonii isolated from geranium in Serbia. Plant Dis. 100:164-170.

Geranium leaves and stems with symptoms of bacterial blight were collected from commercial greenhouses during the last decade in Serbia. In total, 17 isolates with colony morphology typical for the genus Xanthomonas were characterized with pathogenicity, biochemical, serological, and molecular assays. All 17 isolates reacted positive in a polymerase chain reaction (PCR) using XcpM1 and XcpM2 primers specific for Xanthomonas hortorum pv. pelargonii. In pathogenicity tests on Pelargonium zonale (leaf and stem inoculation), all isolates caused typical symptoms on leaves starting 2 days after inoculation as sunken, water-soaked, irregular lesions, and 6 to 8 days after inoculation on stems as necrotic lesions also showing yellow

exudate. Symptoms resulted in general wilting of inoculated plants 20 days after inoculation. Selected phenotypic tests indicated that all isolates showed the same results as described for the bacterium $X$. hortorum pv. pelargonii. Repetitive sequence-based PCR typing using BOX and ERIC revealed that all isolates showed two fingerprinting profiles but (GTG) $)_{5}$ and REP did not reveal differences. Multilocus sequence typing of partial sequences of rpoD, dnaK, fyuA, and gyrB genes of tested isolates and sequences obtained from GenBank of Xanthomonas pathovar pathotype strains did not reveal genetic variability among the isolates, showing the same gene sequence pattern.
\end{abstract}

Bacterial blight, caused by Xanthomonas hortorum pv. pelargonii (Brown 1923; Vauterin et al. 1995), is a serious disease of vegetatively propagated geranium (Pelargonium spp.) worldwide (Daughtrey and Wick 1993; Horst and Nelson 1985; Janse 2005; Mirik et al. 2010; Nameth et al. 1999). Bacterial blight of geranium was recognized for the first time by Brown (1923) in the United States and, since then, it has been reported from Africa (Egypt, Morocco, and South Africa), Asia (India, Iran, Japan, and Turkey), Australia, Canada, Europe (Austria, Belgium, Denmark, France, Germany, Greece, Hungary, Italy, The Netherlands, Portugal, Romania, Sweden, Switzerland, and the United Kingdom), South America (Argentina and Brazil), the United States, and the former USSR (Bradbury 1986; Janse 2005). Occurrence of bacterial blight of geranium in Serbia was first reported by Arsenijević in 1988 (Arsenijević 1988), and a widespread outbreak of the disease was observed during the last decade in commercial greenhouses in Vojvodina Province (Davidović 2014).

Bacterial blight of geranium caused crop losses up to 10 to $15 \%$ (Nameth et al. 1999). Extensive financial losses have been reported from the United States (Janse 2005) and losses up to 100\% may occur, depending on the cultivar involved (Anonymous 1990). X. hortorum pv. pelargonii attacks leaves and stems of geranium. Anonymous (1990) reported two types of symptoms on diseased leaves: (i) small, round, water-soaked spots, in time developing into angular, slightly sunken, well-defined lesions, often surrounded by a yellow halo; the spots eventually turn dark brown to black and become hard and dry, leaves quickly wilt and die, and may fall off or hang on the plant; or (ii) a wilting of the leaf margin that occurs in some cultivars, resulting in large angular (V-shaped), yellow, or dead areas bounded by the veins; these leaves soon wither and hang on the petiole or drop off. The stem rot phase, called "black rot", starts when bacteria migrate

Corresponding author: T. Popović; E-mail: tanjaizbis@gmail.com

Accepted for publication 13 June 2015.

http://dx.doi.org/10.1094/PDIS-03-15-0295-RE

(C) 2016 The American Phytopathological Society into the vascular tissue that shows yellow-brown discoloration, through the petiole into the branches and stem, which rapidly turns gray to blackish brown. The roots are blackened but not decayed. Whole infected plants gradually wilt (Dougherty et al. 1974; Janse 2005). When infected plants are cultivated under conditions unfavorable for symptom development, they often remain asymptomatic and the bacterium survives on plant surfaces (epiphytically) or in latent infections within plants (Manulis et al. 1994). Cuttings from asymptomatic, latently infected plants used for propagation are the major means of dispersal of the pathogen (Daughtrey and Wick 1993). Considering the fact that all commercial cultivars of geranium are susceptible to $X$. hortorum $\mathrm{pv}$. pelargonii, the only method for controlling the disease is the use of disease-free planting material (Griesbach and Olbricht 2002; Janse 2005; Manulis et al. 1994).

Detection and identification of $X$. hortorum pv. pelargonii is based on isolations of the pathogen on nutrient medium, bioassays, and a biochemical tests (Schaad 1988); and, more recently, also on serological assays and DNA-based molecular techniques (Alvarez 2004; Anderson and Nameth 1990; Benedict et al. 1990; Chittaranjan and De Boer 1997; Glick et al. 2002; Manulis et al. 1994; Mirik et al. 2010; Sulzinski et al. 1995, 1996; Tuinier and Stephens 1989; Zhang et al. 2009). The objective of this study was to apply different techniques to identify recent isolates of $X$. hortorum pv. pelargonii obtained from nurseries in Serbia and to analyze the genetic population structure using diverse DNA typing methods: namely, repetitive sequence-based polymerase chain reaction (rep-PCR) and multilocus sequence typing (MLST).

\section{Materials and Methods}

Sample collection. During the last decade, frequent appearance of bacterial blight disease of geranium (Pelargonium zonale) plants was recorded in commercial greenhouses in the Urban Public Enterprise "Gradsko Zelenilo" in the Serbian city Novi Sad. The main symptom observed in the collected samples was blackening and rotting of the stem. In rare cases, wilting of the leaves and petioles followed by $\mathrm{V}$-shaped yellowing was observed.

Isolation and purification of bacterial isolates. Geranium samples were first washed in water and dried at room temperature. Small pieces were cut from the margin of diseased and healthy tissue, then macerated 
in $3 \mathrm{ml}$ of sterilized distilled water for $10 \mathrm{~min}$. Subsequently, $50 \mu \mathrm{l}$ of the suspension was plated on nutrient agar (NA) and yeast extract-dextrosecalcium carbonate agar (YDCA) and incubated at $28^{\circ} \mathrm{C}$ for $72 \mathrm{~h}$. Observations were made for the development of typical yellow, convex, small (up to $2 \mathrm{~mm}$ ) bacterial colonies on NA or yellow, translucent, circular, mucoid, and raised colonies (up to $5 \mathrm{~mm}$ ) on YDCA medium. Typical bacterial colonies were subcultured on YDCA. A reference strain of $X$. hortorum pv. pelargonii (NCPPB 3330 of the National Collection of Plant Pathogenic Bacteria, FERA, York, UK) isolated from $P$. zonale (geranium) by Selwood in 1984 in the United Kingdom (http://ncppb. fera.defra.gov.uk/furtherinfo.cfm?ncppb_no=3330) was used for comparison. In total, 17 purified isolates were used for further study (Table 1) and were kept as stock cultures stored at $-20^{\circ} \mathrm{C}$ in Luria Bertani broth (1\% tryptone, $0.5 \%$ yeast extract, $0.5 \% \mathrm{NaCl}<$ and $1.5 \%$ agar) containing $20 \%$ (vol/vol) sterile glycerol.

Pathogenicity tests. Pathogenicity tests were carried out on diseasefree $P$. zonale ('Tango') plants under artificial inoculation conditions. Tests were performed with 3-day-old X. hortorum pv. pelargonii cultures grown on YDCA using two methods: (i) injecting leaves and stems with a bacterial suspension $\left(10^{7} \mathrm{CFU} \mathrm{ml}{ }^{-1}\right.$ in sterile distilled water) using a hypodermic syringe (Wainwright and Nelson 1972) and (ii) making a small incision in the stem with a sterile scalpel dipped in a bacterial suspension $\left(10^{8} \mathrm{CFU} \mathrm{ml}{ }^{-1}\right.$ in sterile distilled water), according to Griesbach and Tyrach (1999). Sterile distilled water served as a negative control and plants inoculated with the reference strain NCPPB 3330 were taken as positive control. Inoculated plants were kept in a controlled growth chamber (temperature $24 \pm 2^{\circ} \mathrm{C}, 70$ to $80 \%$ relative humidity, and a photoperiod of $16 \mathrm{~h}$ of light and $8 \mathrm{~h}$ of darkness) for 3 weeks. Three replicate plants were inoculated with each of the 17 isolates as well as controls. Inoculated plants were arranged in the growth chamber according to a randomized complete block design. Disease was rated at weekly intervals $(7,14$, and 21 days after inoculation [DAI] ) according to the following scales: 1 to $6(1=$ no symptoms, $2=1$ to $10 \%, 3=11$ to $25 \%, 4=26$ to $50 \%, 5=51$ to $75 \%$, and $6=76$ to $100 \%$ leaf necrosis $)$ for leaf infection and 1 to $6(1=$ symptomless, 2 = slight symptoms, 3 = about one-third of the plant with symptoms, $4=$ about half of the plant with symptoms, $5=$ about two-thirds of the plant with symptoms, and $6=$ plant dead) for stem infection (Griesbach and Tyrach 1999). All obtained data were evaluated by analysis of variance (ANOVA) with the Minitab 16.1.0 Statistics software package. When the $F$ test was significant, means were separated by Tukey's multiple range test at $P<0.05$.

The bacterium was reisolated from typical symptoms on test plants and compared with the reference strain of $X$. hortorum pv. pelargonii (NCPPB 3330) by studying the colony characteristics, reaction in the gram stain, and cell morphology.
Physiological and biochemical characteristics. Physiological and biochemical characteristics were studied according to Dye (1962) and Lelliott and Stead (1987). For all tests, isolates were grown on YDCA at $28^{\circ} \mathrm{C}$ for $48 \mathrm{~h}$. Reference strain NCPPB 3330 was used in all tests as positive control.

Double-antibody sandwich enzyme-linked immunosorbent assay. Serological identification of the isolates was performed using $X$. hortorum pv. pelargonii-specific polyclonal antibodies (LOEWE Biochemica $\mathrm{GmbH}$ ) in double-antibody sandwich enzyme-linked immunosorbent assay (DAS-ELISA) according to the manufacturer's instructions and using their positive and negative controls. Absorbance was recorded at $405 \mathrm{~nm}\left(\mathrm{~A}_{405}\right)$ using a microplate reader (ELX800 BIO-TEK). Samples were considered to be positive when $\mathrm{A}_{405}$ values exceeded the mean of the negative control by at least a factor two.

Genomic DNA Extraction. Total genomic DNA was prepared using a modification of the procedure of Ausubel et al. (1992). Cultures of all 17 isolates and the reference strain NCPPB 3330 were grown on YDCA for $48 \mathrm{~h}$ at $26^{\circ} \mathrm{C}$. Bacterial cells were washed in $1.5 \mathrm{ml}$ of sterile distilled water and centrifuged at $4,000 \times g$ for $10 \mathrm{~min}$ at $4^{\circ} \mathrm{C}$. The resulting pellet was washed twice in $500 \mu \mathrm{l}$ of $0.85 \% \mathrm{NaCl}$, recentrifuged, and washed once in $0.1 \mathrm{M} \mathrm{NaPO}_{4}$ buffer, $\mathrm{pH}$ 6.8. Cells were treated with $10 \%$ sodium dodecyl sulfate and with proteinase $\mathrm{K}$ at $37^{\circ} \mathrm{C}$ for $1 \mathrm{~h}$. DNA was purified by adding $100 \mu \mathrm{l}$ of $5 \mathrm{M} \mathrm{NaCl}$ and $80 \mu \mathrm{l}$ of $10 \%$ hexadecyltrimethyl ammonium bromide solution in $1 \mathrm{M} \mathrm{NaCl}$ at $65^{\circ} \mathrm{C}$ for $10 \mathrm{~min}$. DNA was extracted with an

Table 2. Primers used in this study

\begin{tabular}{|c|c|}
\hline Name & Primers \\
\hline \multirow[t]{2}{*}{ ХсрМ1/ХсрМ2 } & XcpM1 (5-ACGCGCTACCAAAAGGCAAAGAG-3') \\
\hline & ХсрM2 (5-GATCTGCGGTTGTCCTGAAGATTGG-3') \\
\hline \multirow[t]{2}{*}{ ERIC } & ERIC1R (5'-ATGTAAGCTCCTGGGGATTCAC-3') \\
\hline & ERIC2 (5'-AAGTAAGTGACTGGGGTGAGCG-3') \\
\hline \multirow[t]{2}{*}{ REP } & REP1R-I (5'-IIIICGICGICATCIGGC-3') \\
\hline & REP2-I (5'-ICGICTTATCIGGCCTAC-3') \\
\hline $\mathrm{BOX}$ & BOXA1R (5'-CTACGGCAAGGCGACGCTGACG-3') \\
\hline$(\mathrm{GTG})_{5}$ & GTG5 (5'-GTGGTGGTGGTGGTG-3') \\
\hline \multirow[t]{2}{*}{$r p o D$} & XrpoD1F (TGGAACAGGGCTATCTGACC) \\
\hline & XrpoD1R (CATTCYAGGTTGGTCTGRTT) \\
\hline \multirow[t]{2}{*}{ dnaK } & XdnaK1F (GGTGGAAGACCTGGTCAAGA) \\
\hline & XdnaK1R (TCCTTGACYTCGGTGAACTC) \\
\hline \multirow[t]{2}{*}{ fyuA } & XfyuA1F (AGCTACGAYGTGCGYTACGA) \\
\hline & XfyuA1R (GTTCACGCCRAACTGGTAG) \\
\hline \multirow[t]{2}{*}{ gyr $B$} & XgyrB1F (ACGAGTACAACCCGGACAA) \\
\hline & XgyrB1R (CCCATCARGGTGCTGAAGAT) \\
\hline
\end{tabular}

Table 1. Bacterial isolates obtained from diseased geranium used in this study, date of isolation, repetitive sequence-based polymerase chain reaction (rep-PCR) clusters, and GenBank accession numbers

\begin{tabular}{|c|c|c|c|c|c|c|c|c|c|c|c|c|}
\hline \multirow[b]{2}{*}{ Strain name } & \multirow[b]{2}{*}{ Organ } & \multirow[b]{2}{*}{ Host cultivar } & \multirow[b]{2}{*}{ Year of isolation } & \multirow[b]{2}{*}{ Location } & \multicolumn{4}{|c|}{ rep-PCR } & \multicolumn{4}{|c|}{ GenBank Accession numbers } \\
\hline & & & & & ERIC & REP & BOX & $(\text { GTG })_{5}$ & $r p o D$ & dnaK & fyuA & gyrB \\
\hline KBNS150 & Petiole & Tango & 2005 & Novi Sad & I & I & I & I & KP899940 & KP899957 & KP899974 & KP899991 \\
\hline KBNS151 & Petiole & Tango & 2005 & Novi Sad & I & I & I & I & KP899941 & KP899958 & KP899975 & KP899992 \\
\hline KBNS152 & Petiole & Tango & 2005 & Novi Sad & I & I & I & I & KP899942 & KP899959 & KP899976 & KP899993 \\
\hline KBNS153 & Leaf & Tango & 2007 & Novi Sad & I & I & I & I & KP899943 & KP899960 & KP899977 & KP899994 \\
\hline KBNS154 & Leaf & Tango & 2007 & Novi Sad & I & I & I & I & KP899944 & KP899961 & KP899978 & KP899995 \\
\hline KBNS155 & Stem & Tango & 2010 & Novi Sad & II & I & II & I & KP899945 & KP899962 & KP899979 & KP899996 \\
\hline KBNS156 & Stem & Tango & 2010 & Novi Sad & II & I & II & I & KP899946 & KP899963 & KP899980 & KP899997 \\
\hline KBNS157 & Stem & Tango & 2010 & Novi Sad & II & I & II & I & KP899947 & KP899964 & KP899981 & KP899998 \\
\hline KBNS158 & Stem & Tango & 2010 & Novi Sad & II & I & II & I & KP899948 & KP899965 & KP899982 & KP899999 \\
\hline KBNS159 & Stem & Tango & 2010 & Novi Sad & II & I & II & I & KP899949 & KP899966 & KP899983 & KP900000 \\
\hline KBNS160 & Stem & Tango & 2010 & Novi Sad & II & I & II & I & KP899950 & KP899967 & KP899984 & KP900001 \\
\hline KBNS161 & Stem & Tango & 2010 & Novi Sad & II & I & II & I & KP899951 & KP899968 & KP899985 & KP900002 \\
\hline KBNS162 & Petiole & Tango & 2011 & Novi Sad & I & I & I & I & KP899952 & KP899969 & KP899986 & KP900003 \\
\hline KBNS163 & Petiole & Tango & 2011 & Novi Sad & I & I & I & I & KP899953 & KP899970 & KP899987 & KP900004 \\
\hline KBNS164 & Petiole & Tango & 2011 & Novi Sad & I & I & I & I & KP899954 & KP899971 & KP899988 & KP900005 \\
\hline KBNS165 & Leaf & Tango & 2011 & Novi Sad & I & I & I & I & KP899955 & KP899972 & KP899989 & KP900006 \\
\hline KBNS166 & Leaf & Tango & 2011 & Novi Sad & I & I & I & I & KР899956 & KР899973 & КР899990 & KP900007 \\
\hline
\end{tabular}


equal volume of chloroform and centrifuged for $10 \mathrm{~min}$ at $8,000 \times g$. The aqueous phase was transferred to a fresh tube and precipitated by adding 0.6 volume of isopropanol. The precipitated DNA was washed with $500 \mu \mathrm{l} 70 \%$ of ethanol and redissolved in $100 \mu \mathrm{l}$ of Tris-EDTA (10 mM Tris and $1 \mathrm{mM}$ EDTA, $\mathrm{pH}$ 8.0) and quantified spectrophotometrically at $260 \mathrm{~nm}$.

PCR identification. Molecular identification of putative $X$. hortorum pv. pelargonii isolates was performed using the $X$. hortorum $\mathrm{pv}$. pelargonii-specific primer pair XcpM1 and XcpM2, given by Sulzinski et al. (1996) (Table 2). PCR was carried out in a 25- $\mu$ l volume of Taq reaction buffer $(50 \mathrm{mM}$ Tris- $\mathrm{HCl}, \mathrm{pH} 9.0$, and $20 \mathrm{mM}$ ammonium sulfate) containing $1.0 \mu \mathrm{l}$ of template DNA, 100 pmol each primer, $200 \mu \mathrm{M}$ each deoxynucleotide triphosphate, $2.0 \mathrm{mM} \mathrm{MgCl}_{2}$, and

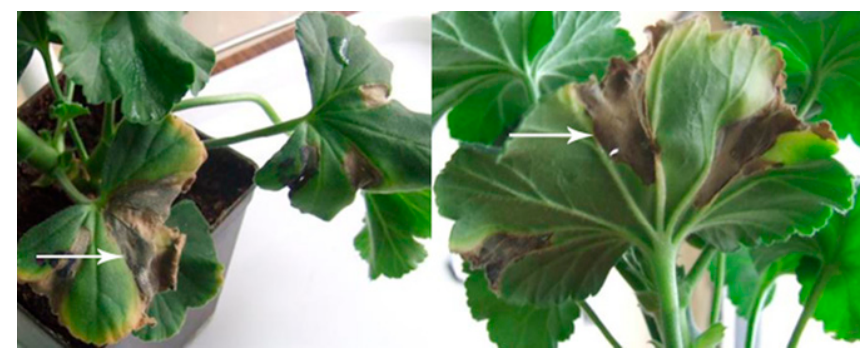

Fig. 1. "V" symptom on geranium leaves caused by the bacterium Xanthomonas hortorum pv. pelargonii. Artificial infection.

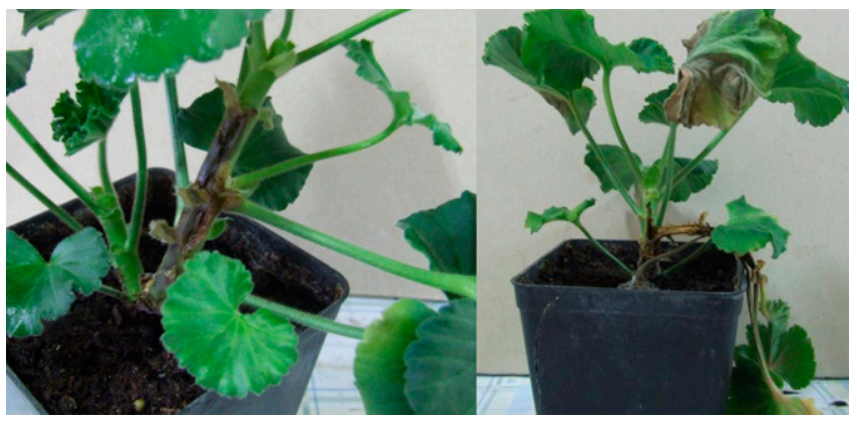

Fig. 2. Blackening and wilting of the geranium stem caused by the bacterium Xanthomonas hortorum pv. pelargonii. Artificial infection.
1.0 U of Taq DNA polymerase (Fermentas). Negative controls, in which template was replaced with the same volume of sterile distilled water, were included with each amplification. Additionally, reference strains of other Xanthomonas pathovars (X. arboricola pv. juglandis CFBP 2528, X. axonopodis pv. phaseoli GSPB 1241, and X. campestris pv. campestris NCPPB 1144) were tested as templates for PCR amplification. Amplifications using the $\mathrm{XcpMl} / \mathrm{XcpM} 2$ primer pair were programmed for 1 cycle of $4 \mathrm{~min}$ at $94^{\circ} \mathrm{C}$ and 30 cycles of $1 \mathrm{~min}$ at $94^{\circ} \mathrm{C}, 1 \mathrm{~min}$ at $64^{\circ} \mathrm{C}$, and $1 \mathrm{~min}$ at $72^{\circ} \mathrm{C}$. PCR amplifications were performed in a Mastercycler personal model (Eppendorf).

rep-PCR. For rep-PCR, the following primers were used: ERIC (ERIC1R and ERIC2), REP (REP1R-I and REP2-I), BOX (BOXA1R), and (GTG) $)_{5}$ (Louws et al. 1994; Versalovic et al. 1994). Amplification of DNA bands was performed in a total volume of $25 \mu$ l containing $67 \mathrm{mM}$ Tris- $\mathrm{HCl}$ (pH 8.8); $25 \mathrm{mM} \mathrm{MgCl} 2 ; 125 \mu \mathrm{M}$ dATP, dCTP, dGTP, and dTTP each; $2 \mathrm{U}$ of TaqDNA polymerase (Fermentas); and 100 pmol each primer (pair). A 40-ng quantity of genomic DNA and ultrapure water as a negative control were added to the reaction tubes. rep-PCR conditions were as previously described (de Bruijn 1992). Amplification of PCR was performed with a Mastercycler personal model (Eppendorf) using the following cycles: 1 initial cycle at $95^{\circ} \mathrm{C}$ for $7 \mathrm{~min} ; 30$ cycles of denaturation at $94^{\circ} \mathrm{C}$ for $1 \mathrm{~min}$, annealing at $40,44,52$, or $53^{\circ} \mathrm{C}$ for 1 min with (GTG) $)_{5}$, REP, ERIC, and BOX primers, respectively, and extension at $65^{\circ} \mathrm{C}$ for $8 \mathrm{~min}$; with a single final extension cycle at $65^{\circ} \mathrm{C}$ for $15 \mathrm{~min}$ and a final soak at $4^{\circ} \mathrm{C}$. The PCR amplifications were performed in triplicate. Amplified PCR products were separated by gel electrophoresis on $1 \%$ agarose gels in $0.5 \times$ Tris-acetate-EDTA buffer for $1 \mathrm{~h}$ at $5 \mathrm{~V} / \mathrm{cm}$, stained with ethidium bromide at $0.05 \mu \mathrm{ml}^{-1}$, and visualized under UV illumination. Fingerprints generated from different strains were compared visually.

MLST. Partial coding sequences of the housekeeping genes $r p o D$ (RNA polymerase $\sigma$ factor), dnaK (chaperone protein), fyuA (tonBdependent receptor), and $g y r B$ (DNA gyrase B subunit) were amplified for 17 representative isolates with genetically different rep-PCR profiles, using the primers listed in Table 2 (Young et al. 2008).

PCR amplifications were performed with initial denaturation at $94^{\circ} \mathrm{C}$ for $3 \mathrm{~min} ; 30$ cycles of denaturation at $94^{\circ} \mathrm{C}$ for $30 \mathrm{~s}$, annealing at $54^{\circ} \mathrm{C}$ for $30 \mathrm{~s}$, and extension at $72^{\circ} \mathrm{C}$ for $1 \mathrm{~min}$; and a final extension at $72^{\circ} \mathrm{C}$ for $10 \mathrm{~min}$. The PCR products $(25 \mu \mathrm{l})$ were purified and then sequenced (Macrogene). The distance dendrogram of the $r p o D$, $d n a K, f y u A$, and $g y r B$ gene sequences determined in this study was generated by the Mega 6.0 package (Tamura et al. 2013) according to the neighbor-joining $(\mathrm{NJ})$ method.

Table 3. Disease severity on Pelargonium zonale ('Tango') after inoculations with bacterial isolates ${ }^{\mathrm{z}}$

\begin{tabular}{|c|c|c|c|c|c|c|c|c|c|}
\hline \multirow[b]{2}{*}{ Strain name } & \multicolumn{3}{|c|}{ Leaves injection } & \multicolumn{3}{|c|}{ Stem injection } & \multicolumn{3}{|c|}{ Stem incision } \\
\hline & 7 DAI & 14 DAI & 21 DAI & 7 DAI & 14 DAI & 21 DAI & 7 DAI & 14 DAI & 21 DAI \\
\hline KBNS150 & $2.7 \mathrm{~b}$ & $4.3 \mathrm{ab}$ & $4.7 \mathrm{~b}$ & $2.0 \mathrm{~b}$ & $3.7 \mathrm{~b}$ & $5.0 \mathrm{ab}$ & $1.7 \mathrm{a}$ & $3.3 \mathrm{a}$ & $5.3 \mathrm{a}$ \\
\hline KBNS151 & $3.0 \mathrm{ab}$ & $4.0 \mathrm{~b}$ & $5.0 \mathrm{~b}$ & $2.0 \mathrm{~b}$ & $3.7 \mathrm{~b}$ & $4.7 \mathrm{~b}$ & $2.0 \mathrm{a}$ & $3.7 \mathrm{a}$ & $5.0 \mathrm{a}$ \\
\hline KBNS152 & $3.0 \mathrm{ab}$ & $4.3 \mathrm{ab}$ & $4.7 \mathrm{~b}$ & $2.0 \mathrm{~b}$ & $4.0 \mathrm{ab}$ & $4.7 \mathrm{~b}$ & $2.0 \mathrm{a}$ & $3.3 \mathrm{a}$ & $5.0 \mathrm{a}$ \\
\hline KBNS153 & $2.7 \mathrm{~b}$ & $4.0 \mathrm{~b}$ & $5.0 \mathrm{~b}$ & $2.0 \mathrm{~b}$ & $4.0 \mathrm{ab}$ & $4.7 \mathrm{~b}$ & $1.7 \mathrm{a}$ & $3.0 \mathrm{a}$ & $5.3 \mathrm{a}$ \\
\hline KBNS154 & $2.7 \mathrm{~b}$ & $4.0 \mathrm{~b}$ & $5.0 \mathrm{~b}$ & $2.0 \mathrm{~b}$ & $4.0 \mathrm{ab}$ & $4.7 \mathrm{~b}$ & $1.7 \mathrm{a}$ & $3.0 \mathrm{a}$ & $5.0 \mathrm{a}$ \\
\hline KBNS155 & $3.7 \mathrm{ab}$ & $5.7 \mathrm{a}$ & $6.0 \mathrm{a}$ & $3.0 \mathrm{a}$ & $5.0 \mathrm{a}$ & $5.7 \mathrm{ab}$ & $2.0 \mathrm{a}$ & $3.7 \mathrm{a}$ & $5.7 \mathrm{a}$ \\
\hline KBNS156 & $4.0 \mathrm{a}$ & $5.7 \mathrm{a}$ & $6.0 \mathrm{a}$ & $3.0 \mathrm{a}$ & $5.0 \mathrm{a}$ & $6.0 \mathrm{a}$ & $2.0 \mathrm{a}$ & $4.0 \mathrm{a}$ & $5.3 \mathrm{a}$ \\
\hline KBNS157 & $3.7 \mathrm{ab}$ & $5.3 \mathrm{ab}$ & $6.0 \mathrm{a}$ & $2.7 \mathrm{a}$ & $4.7 \mathrm{ab}$ & $5.7 \mathrm{ab}$ & $2.0 \mathrm{a}$ & $4.0 \mathrm{a}$ & $5.0 \mathrm{a}$ \\
\hline KBNS158 & $4.0 \mathrm{a}$ & $5.3 \mathrm{ab}$ & $6.0 \mathrm{a}$ & $3.0 \mathrm{a}$ & $5.0 \mathrm{a}$ & $6.0 \mathrm{a}$ & $2.0 \mathrm{a}$ & $3.3 \mathrm{a}$ & $5.7 \mathrm{a}$ \\
\hline KBNS159 & $3.7 \mathrm{ab}$ & $5.7 \mathrm{a}$ & $6.0 \mathrm{a}$ & $3.0 \mathrm{a}$ & $5.0 \mathrm{a}$ & $5.7 \mathrm{ab}$ & $2.0 \mathrm{a}$ & $3.7 \mathrm{a}$ & $5.3 \mathrm{a}$ \\
\hline KBNS160 & $3.7 \mathrm{ab}$ & $5.3 \mathrm{ab}$ & $6.0 \mathrm{a}$ & $2.7 \mathrm{a}$ & $4.7 \mathrm{ab}$ & $6.0 \mathrm{a}$ & $2.0 \mathrm{a}$ & $4.0 \mathrm{a}$ & $5.0 \mathrm{a}$ \\
\hline KBNS161 & $4.0 \mathrm{a}$ & $5.7 \mathrm{a}$ & $6.0 \mathrm{a}$ & $3.0 \mathrm{a}$ & $5.0 \mathrm{a}$ & $6.0 \mathrm{a}$ & $2.0 \mathrm{a}$ & $4.0 \mathrm{a}$ & $5.7 \mathrm{a}$ \\
\hline KBNS162 & $3.0 \mathrm{ab}$ & $4.3 \mathrm{ab}$ & $5.0 \mathrm{~b}$ & $2.0 \mathrm{~b}$ & $3.7 \mathrm{~b}$ & $4.7 \mathrm{~b}$ & $2.0 \mathrm{a}$ & $3.3 \mathrm{a}$ & $5.0 \mathrm{a}$ \\
\hline KBNS163 & $2.7 \mathrm{~b}$ & $4.0 \mathrm{~b}$ & $5.0 \mathrm{~b}$ & $2.0 \mathrm{~b}$ & $4.0 \mathrm{ab}$ & $5.0 \mathrm{ab}$ & $1.7 \mathrm{a}$ & $3.7 \mathrm{a}$ & $5.0 \mathrm{a}$ \\
\hline KBNS164 & $2.7 \mathrm{~b}$ & $4.0 \mathrm{~b}$ & $5.0 \mathrm{~b}$ & $2.0 \mathrm{~b}$ & $3.7 \mathrm{~b}$ & $5.0 \mathrm{ab}$ & $2.0 \mathrm{a}$ & $3.0 \mathrm{a}$ & $5.0 \mathrm{a}$ \\
\hline KBNS165 & $3.0 \mathrm{ab}$ & $4.3 \mathrm{ab}$ & $4.7 \mathrm{~b}$ & $2.0 \mathrm{~b}$ & $3.7 \mathrm{~b}$ & $5.0 \mathrm{ab}$ & $1.7 \mathrm{a}$ & $3.3 \mathrm{a}$ & $5.3 \mathrm{a}$ \\
\hline KBNS166 & $3.0 \mathrm{ab}$ & $4.3 \mathrm{ab}$ & $5.0 \mathrm{~b}$ & $2.0 \mathrm{~b}$ & $4.0 \mathrm{ab}$ & $4.7 \mathrm{~b}$ & $1.7 \mathrm{a}$ & $3.3 \mathrm{a}$ & $5.0 \mathrm{a}$ \\
\hline NCPPB3330 & $3.7 \mathrm{ab}$ & $5.7 \mathrm{a}$ & $6.0 \mathrm{a}$ & $3.0 \mathrm{a}$ & $5.0 \mathrm{a}$ & $6.0 \mathrm{a}$ & $2.0 \mathrm{a}$ & $4.0 \mathrm{a}$ & $5.7 \mathrm{a}$ \\
\hline
\end{tabular}

z DAI = days after inoculation. Differences between means within each column followed by the same letter are not significantly different $($ Tukey test, $P<0.05)$. Comparisons are within each method only and not between methods. 
The partial coding sequences of the $r p o D, d n a K, f y u A$, and $g y r B$ gene data reported in this work from the $17 X$. hortorum pv. pelargonii strains were submitted to the GenBank database with accession numbers KP899940 to KP899956 for rpoD, KP899957 to KP899973 for dnaK, KP899974 to KP899990 for fyuA, and KP899991 to KP900007 for gyrB gene (Table 1).

Phylogenetics. In order to evaluate the evolutionary relationship between the 17 Serbian $X$. hortorum pv. pelargonii isolates and the pathotype reference strains obtained from the PAMDB database (http://genome.ppws.vt.edu/cgi-bin/MLST/home.pl), an unrooted phylogenetic tree was built. Phylogenetic analyses were performed with nucleotide sequences, using four housekeeping genes ( $r p o D$, dnaK, fyuA, and $g y r B$ ). Sequences were assembled and edited with FINCHTV v.1.4.0 (http://www.geospiza.com) and aligned using CLUSTALW integrated into MEGA6 software (Tamura et al. 2013). All ambiguous and terminal sequences were edited before data analysis. Each $X$. hortorum pv. pelargonii strain was characterized by sequence typing and allele assignment using the PAMDB database. Phylogenetic trees and bootstrap values for the nucleotide and amino acid sequences of each gene fragment and for concatenated data were obtained using the NJ analyses integrated into MEGA6 software (Tamura et al. 2013).

\section{Results}

Characterization of isolates. Typical Xanthomonas colonies were isolated from diseased geranium plants collected in commercial greenhouses during the last decade. Colonies on NA were pale yellow, slimy, glistening, and round in shape (with a diameter of $2 \mathrm{~mm}$ ) and, on YDCA, were yellow, translucent, circular, mucoid, and raised (approximately 3 to $6 \mathrm{~mm}$ ) after 3 days of incubation.

The 17 tested isolates, artificially inoculated into leaves of geranium ( $P$. zonale Tango) using a hypodermic syringe, first developed sunken, water-soaked, irregular lesions faintly visible 2 DAI but clearly defined 3 DAI. The 4-DAI lesions became dark green, greasy, and irregular on the upper side of leaves and water-soaked on the lower side of leaves. The 6-DAI lesions spread to the leaf edges, and interveinal necrosis with haloes was observed (disease ratings 2 to 4 ). The 8-DAI lesions merged bounded by the veins (V-shaped), with yellow haloes (Fig. 1). After 12 DAI, necrosis covered two-thirds of inoculated leaves and the other leaf parts gradually dried (disease ratings 4 to $6)$. In the final stage (18 DAI), severe wilting of inoculated leaves was recorded and, at $20 \mathrm{DAI}$, most of the leaves dropped or were fully necrotic and wilting (disease ratings 4 to 6 ). These symptoms were

Table 4. Results from analysis of variance for isolates and inoculation methods

\begin{tabular}{lcc}
\hline Source & dt & $\boldsymbol{P}$ significance $^{\mathbf{z}}$ \\
\hline Isolates & 17 & $* *$ \\
Methods & 2 & $* *$ \\
Isolates $\times$ methods & 34 & $*$ \\
\hline
\end{tabular}

${ }^{\mathrm{z}}$ For $F$ tests, $*$ and $* *$ indicate significant at the $P<0.05$ and 0.01 level of significance, respectively.

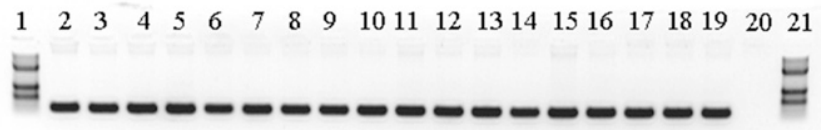

Fig. 3. Gel electrophoresis analysis of polymerase chain reaction products amplified with the Xanthomonas hortorum pv. pelargonii XcpM1/XcpM2-specific primers. Lanes 1 and 21, DNA molecular size marker (GeneRuler DNA 100-bp Ladder Mix); lane 2, NCPPB3330; lane 3, KBNS150; lane 4, KBNS151; lane 5, KBNS152; lane 6, KBNS153; lane 7, KBNS154; lane 8, KBNS155; lane 9, KBNS156; lane 10, KBNS157; lane 11, KBNS158; lane 12, KBNS159; lane 13, KBNS160; lane 14, KBNS161; lane 15, KBNS162; lane 16, KBNS163; lane 17, KBNS164; lane 18, KBNS165; lane 19, KBNS166; and lane 20, negative control. similar to those caused by reference strain NCPPB 3330. Plants treated with sterile distilled water remained symptomless.

On geranium stems inoculated with a hypodermic syringe, characteristic brown lesions at the point of inoculation, followed by exudates appearing through the crack tissue, were observed within 6 DAI (disease ratings 2 to 3 ). After 12 DAI, two-thirds of stem showed black discoloration (Fig. 2) and leaves became chlorotic and started to dry (disease ratings 3 to 5). Vascular tissue showed dark-brown to black discoloration. In a final stage, stems at 18 to 20 DAI collapsed and rotted (Fig. 2), and leaves were necrotic and dropping (disease ratings 4 to 6). Reference strain NCPPB 3330 induced similar symptoms. No symptoms developed on plants inoculated with sterile distilled water.

Using the leaf and stem inoculation with a hypodermic syringe, significant variation was observed among isolates tested (Table 3). Isolates KBNS155 to -161 and reference strain NCPPB 3330 were most pathogenic, as indicated by their disease ratings ( 5 to 6 ), while isolates KBNS150 to -154 and KBNS162 to -166 were weakly virulent, with lower disease ratings (4 to 5) (Table 3 ).

On geranium stems, inoculated by making a small incision in the stem, first symptoms developed $8 \mathrm{DAI}$, with dark necrotic lesions at the inoculation site; at $12 \mathrm{DAI}$, necrosis merged (diameter of $4 \mathrm{~cm}$ ) and leaves near the inoculation site became chlorotic (disease ratings 3 to 4). Leaves above and below the inoculation points started to dry. At 18 DAI, all lesions on the inoculated stem were merged (disease ratings 5 to 6). On inoculated plants, leaves showed a few types of symptoms: (i) petioles were cracked, and leaves showed chlorotic and necrotic areas and redness at the edges; (ii) leaf petioles were healthy, and leaves were covered with chlorotic and necrotic areas;

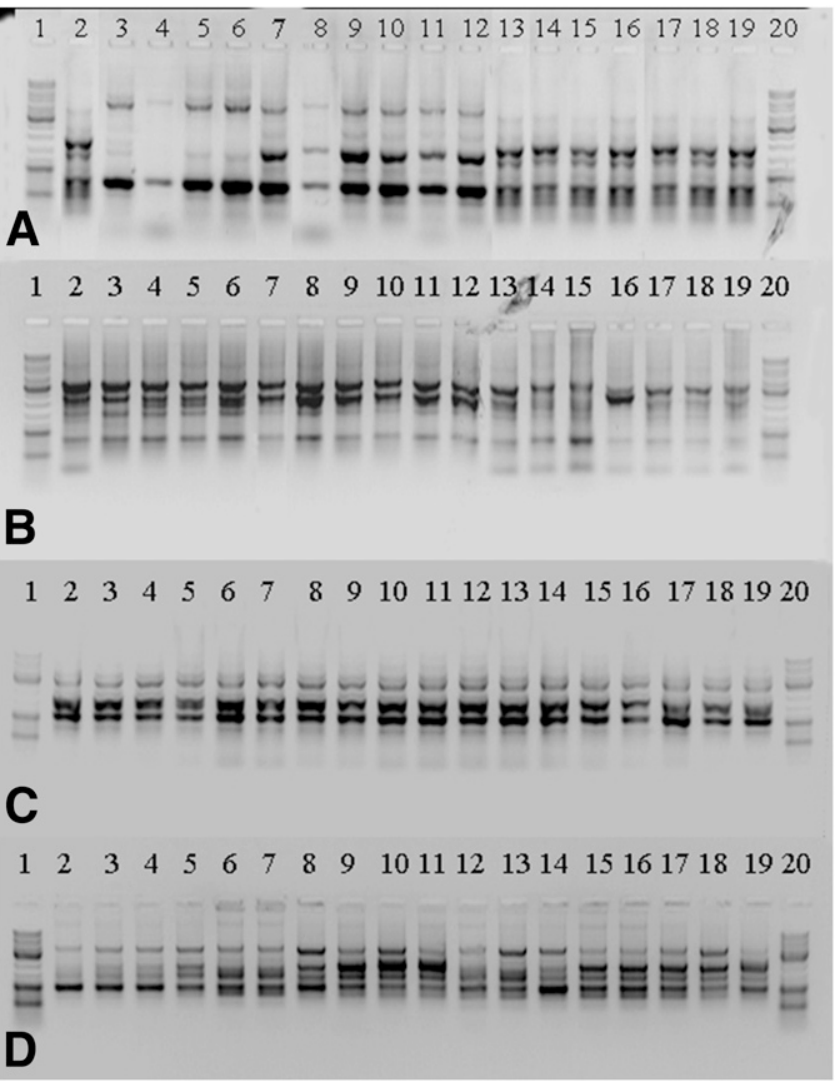

Fig. 4. Agarose gel electrophoresis of repetitive sequence-based polymerase chain reaction A, ERIC; B, BOX; C, REP; and D, (GTG) $)_{5}$ fingerprint patterns obtained from 17 Xanthomonas hortorum pv. pelargonii strains from Serbia and reference strain NCPPB3330. Lanes 1 and 20, DNA molecular size marker (GeneRuler 100-bp DNA Ladder Mix); lane 2, NCPPB3330; lane 3, KBNS150; lane 4, KBNS151; lane 5, KBNS152; lane 6, KBNS153; lane 7, KBNS154; lane 8, KBNS162; lane 9, KBNS163; lane 10, KBNS164; lane 11, KBNS165; lane 12, KBNS166; lane 13, KBNS155; lane 14, KBNS156; lane 15, KBNS157; lane 16, KBNS158; lane 17, KBNS159; lane 18, KBNS160; and lane 19, KBNS161. 
(iii) small leaves fell away and lost turgor, starting from the leaf base; and (iv) older leaves had redness at the edges.

Reference strain NCPPB 3330 caused similar symptoms as described above. Plants inoculated with sterile distilled water remained symptomless. When using the incision method, no differences in virulence was observed (Table 3).

The ANOVA showed significant interaction of isolates and inoculation methods $(P<0.01)$ and interaction between isolates and inoculation methods $(P<0.05)$ (Table 4$)$.

Reisolations showed the same colony morphology as described for original isolates.

Results of the physiological and biochemical tests of the 17 isolates tested matched those of the reference strain NCPPB 3330. All isolates were gram negative, strictly aerobic, oxidase negative, and catalase and levan positive; they produced hydrogen sulfide, did not produce indole, did not reduce nitrate, and hydrolyzed gelatin and aesculin but not starch; they showed tolerance to 0.10 and $0.02 \%$ triphenyl-tetrazolium chloride and produced acid from d-arabinose and trehalose.
DAS-ELISA analysis showed strongly positive reactions for all 17 representative isolates and the reference strain NCPPB 3330 using the $X$. hortorum pv. pelargonii-specific polyclonal antibodies.

In order to confirm pathovar identity, a PCR amplification of a 197-bp fragment with the pathovar-specific primer pair XcpM1/XcpM2 was obtained for all 17 strains tested (Fig. 3). Analyzed Xanthomonas pathovars other than pelargonii did not generate a visible product upon ethidium bromide staining of agarose gels.

Genetic diversity and phylogenetic analysis. Results of (GTG) BOX, REP, and ERIC analyses of the $17 \mathrm{X}$. pelargonii isolates, together with reference strain NCPPB 3330, are shown in Figure 4.

Differences among strains were assessed visually on the basis of migration patterns of the PCR products, which ranged in size from approximately $200 \mathrm{bp}$ to over $10 \mathrm{~kb}$. rep-PCR and (GTG) $)_{5}$ DNA profiles produced visually identical DNA patterns for all strains tested. DNA profiles using BOX and ERIC primers were complex and showed two DNA profile types (Fig. 4). One group included strains originating from leaves and petioles and the second group contained isolates obtained from stems and the reference strain NCPPB 3330.

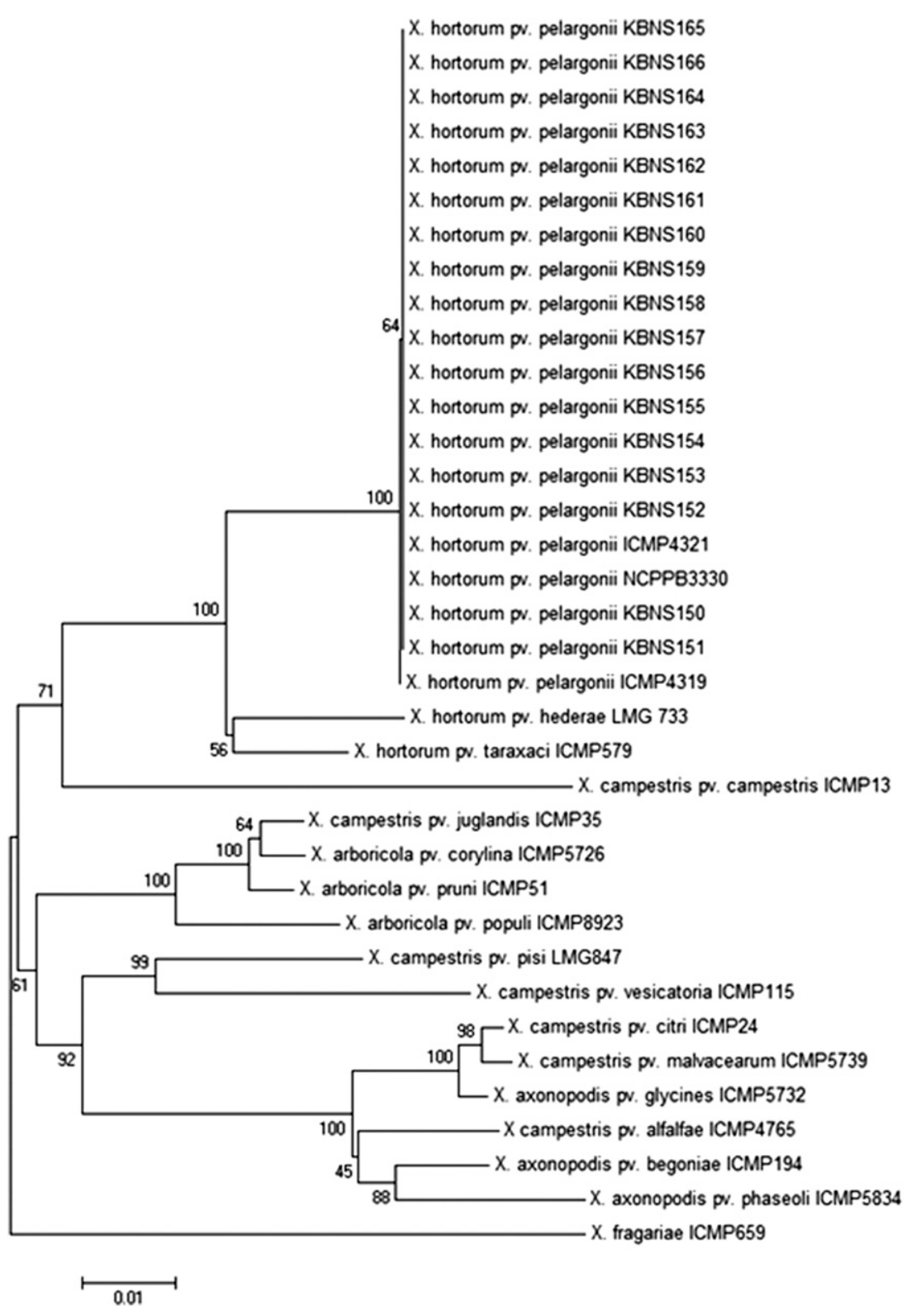

Fig. 5. Neighbor-joining tree of nucleotide sequences for the concatenated sequence data of $r p o D$, dnaK, fyuA, and gyrB genes of Serbian Xanthomonas hortorum pv. pelargonii strains. For comparison, the sequences of the genes of other Xanthomonas strains are included. Bootstrap values (expressed as percentages of 1,000 replications) are given at the nodes. Bar $=$ estimated nucleotide substitutions per site $=0.01$. 
DNA profiles with (GTG) 5 and REP primers did not show any difference (Fig. 4).

MLST. For further genetic determination of $X$. hortorum pv. pelargonii strains, concatenated data of $r p o D$, dnaK, fyuA, and gyrB gene loci were analyzed. The dendrogram constructed on the basis of the concatenated gene sequences for all 17 isolates and the reference is shown in Figure 5. All Serbian strains together with two X. hortorum pv. pelargonii strains published in the National Center for Biotechnology Information database (ICMP 4321 and ICMP 4319) grouped in a monophyletic cluster. The sequence analysis of the concatenated data of all of the loci of the Serbian X. hortorum pv. pelargonii strains showed clear genetic differences with other Xanthomonas pathovars (Fig. 5).

\section{Discussion}

In this study, 17 isolates of $X$. hortorum pv. pelargonii isolates originating from symptomatic geranium plants were characterized. During collection of the samples, it was observed that the predominant symptom was blackening and stem rot. Although, in the literature, most sources highlight leaf spots as the most common symptom, which leads to the general wilting of whole plants, we did not notice these symptoms on diseased plants in any case. For that reason, we decided to characterize isolates obtained in more detail, using phenotypic and genetic methods and pathogenicity tests. Phenotypic tests completely confirmed results for $X$. hortorum pv. pelargonii as presented by Lelliott and Stead (1987) and Schaad et al. (2001). Strains were also serologically homogeneous in DAS-ELISA.

All Serbian strains were pathogenic to geranium plants. When using leaf and stem inoculation, two virulence groups were observed. One highly virulent group contained isolates KBNS155 to -161 originated from stems, together with reference strain NCPPB 3330; and a second group, with lower virulence, consisted of isolates originated from leaves and petioles (KBNS150 to -154 and KBNS162 to -166).

It is interesting to point out that, in our pathogenicity test, apart from the species $P$. zonale (Tango), we included the species $P$. grandiflorum ('Angel Eyes Burgundy'). Results showed that the latter species exhibited a very high level of resistance to $X$. hortorum pv. pelargonii because, on inoculated leaves, only spots similar to a hypersensitive reaction at the inoculation site developed and, on inoculated stems, no symptoms developed (unpublished data).

Identification of $X$. hortorum pv. pelargonii isolates was further confirmed by PCR, using the specific primer pair XcpMl/XcpM2. This primer pair proved to be very specific in the study of Sulzinski et al. (1996) when isolates of Xanthomonas species and pathovars other than $X$. hortorum pv. pelargonii and including the closely related $X$. hortorum pv. carotae and $X$. hortorum pv. vitians (furthermore also $X$. arboricola pv. juglandis, $X$. arboricola pv. pruni, $X$. axonopodis pv. begoniae, $X$. axonopodis pv. citromelo, $X$. axonopodis pv. malvacearum, $X$. axonopodis pv. manihotis, $X$. axonopodis pv. phaseoli, $X$. campestris pv. campestris, $X$. citri and $X$. vesicatoria) and many isolates of non-xanthomonad plant-pathogenic bacteria were analyzed with the XcpMl/XcpM2 primer pair. All isolates did not generate the $197 \mathrm{bp}$ amplification product, except two out of five isolates of the related $X$. hortorum pv. vitians (this pathogen has never been reported from pelargonium). These results demonstrated the usefulness of PCR method as an easy, speedy, and low cost diagnostic test, particularly useful in routine diagnostic analysis.

The results of DNA fingerprinting techniques (PCR with primers REP, ERIC, BOX, and (GTG) 5 ) showed only two different groups in ERIC and BOX PCR. One group contained isolates from leaves and petioles and the other group was composed of those obtained from stems. These results confirm findings of two different groups obtained in pathogenicity tests (see above). Previous studies (e.g., those using random amplified polymorphic DNA analysis) (Manulis et al. 1994) did not show the existence of those groups. Reference strain X. hortorum pv. pelargonii NCPPB 3330 showed the same features as those for the group of isolates obtained from stems. ERIC and BOX PCR were also found to be suitable methods for subtyping the $X$. arboricola pv. juglandis population at the pathovar level (Ivanović et al. 2015; Kaluzna et al. 2014).
By contrast, $(\mathrm{GTG})_{5}$ and REP PCR fingerprinting did not reveal differences among the Serbian $X$. hortorum pv. pelargonii strains and are apparently not useful to determine genetic diversity among tested strains.

MLST analysis identified all of our isolates as X. hortorum pv. pelargonii and placed them in one cluster, clearly differentiated from other X. hortorum pathovars. The sequence analysis of rpoD, dnaK, $f y u A$, and $g y r B$ genes of Serbian isolates and constructed dendrograms for each gene solely showed phylogenetic congruence with the dendrogram of the concatenated data analysis. Although sequence analysis of the concatenated data accurately portrays the relationship among Xanthomonas strains at the molecular level (Young et al. 2008), results of the present study indicate a lower discriminatory ability when it is performed in a study of genetic diversity of $X$. hortorum pv. pelargonii strains. This analysis is based on a very small portion of the genome and true variation or lack of variation can only be validated upon availability of whole-genome sequences.

Results obtained in this study indicate that some pathogenic and genetic variation exists in the $X$. hortorum pv. pelargonii pathogen population in Serbia when isolated from leaves and petioles or from stems. This finding could provide a basis for further research and understanding of (i) the variation among $X$. hortorum pv. pelargonii populations and their epidemiology and (ii) a deeper insight into the occurrence of leaf and petiole infections on one hand and black stem infections on the other that can be present solely or concomitantly and could possibly lead to a more efficient control of the disease.

\section{Acknowledgments}

We thank S. Bančević, a longtime associate in the Laboratory of Bacteriology, Faculty of Agriculture, Novi Sad. This work was supported by the Ministry of Education, Science and Technological Development, Republic of Serbia (project numbers III43010 and OI173026).

\section{Literature Cited}

Alvarez, A. M. 2004. Integrated approaches for detection of plant pathogenic bacteria and diagnosis of bacterial diseases. Annu. Rev. Phytopathol. 42: 339-366.

Anderson, M. J., and Nameth, S. T. 1990. Development of a polyclonal antibodybased serodiagnostic assay for the detection of Xanthomonas campestris pv. pelargonii in geranium plants. Phytopathology 80:357-360.

Anonymous. 1990. Bacterial diseases of geranium. Reports on Plant Diseases, RPD No. 607. IPM Integrated Pest Management. Online publication. http://ipm. illinois.edu/diseases/series600/rpd607/

Arsenijević, M. 1988. M. Xanthomonas campestris pv. pelargonii (Brown 1923) Dye 1978-A parasite of pelargonium (Pelargonium hortorum Bailey). Zaštita bilja 39:279-289.

Ausubel, F. M., Brent, R., Kingston, R. E., Moore, D. D., Seidman, J. G., Smith, J. A., and Struhl, K. 1992. Current Protocols in Molecular Biology. Greene Publishing Associates and Wiley-Interscience, New York.

Benedict, A. A., Alvarez, A. M., and Pollard, L. W. 1990. Pathovar-specific antigens of Xanthomonas campestris pv. begoniae and X. campestris pv pelargonii detected with monoclonal antibodies. Appl. Environ. Microbiol. 56:572-574.

Bradbury, J. F. 1986. Guide to the Plant Pathogenic Bacteria. CAB International, Wallingford, UK

Brown, N. A. 1923. Bacterial leafspot of geranium in the eastern United States. J. Agric. Res. XXIII, 5:361-372.

Chittaranjan, S., and De Boer, S. H. 1997. Detection of Xanthomonas campestris pv. pelargonii in geranium and greenhouse nutrient solution by serological and PCR techniques. Eur. J. Plant Pathol. 103:555-563.

Daughtrey, M., and Wick, R. L. 1993. Vascular wilt diseases. Pages 237-242 in: Geraniums IV. The Grower's Manual. J. W. White, ed. Ball Publishing, Geneva, IL.

Davidović, A. 2014. Bacterial blight of Pelargonium (Pelargonium zonale). Master thesis, University of Novi Sad, Serbia.

de Bruijn, F. J. 1992. Use of repetitive (repetitive extragenic palindromic and enterobacterial repetitive intergeneric consensus) sequences and the polymerase chain reaction to fingerprint the genomes of Rhizobium meliloti isolates and other soil bacteria. Appl. Environ. Microbiol. 58:2180-2187.

Dougherty, D. E., Powell, C. C., and Larsen, P. O. 1974. Epidemiology and control of bacterial leaf spot and stem rot of Pelargonium hortorum. Phytopathology 64:1081-1083

Dye, D. W. 1962. The inadequacy of the usual determinative test for the identification of Xanthomonas spp. N. Z. J. Sci. 5:393-416.

Glick, D. L., Coffey, C. M., and Sulzinski, M. A. 2002. Simultaneous PCR Detection of the two major bacterial pathogens of geranium. J. Phytopathol. 150:54-59. 
Griesbach, E., and Olbricht, K. 2002. Resistance to Xanthomonas hortorum pv. pelargonii in the genus Pelargonium. Z. Pflanzenkr. Pflanzenschutz 109:553-568.

Griesbach, E., and Tyrach, A. 1999. Evaluation of resistance to Xanthomonas hortorum pv. pelargonii at Pelargonium. Beiträge zur Züchtungsforschung 5, 1:68-69.

Horst, R. K., and Nelson, P. E. 1985. Diseases of Geraniums. Cornell Coop. Ext. Inf. Bull. 201. Ithaca, NY

Ivanović, Ž., Popović, T., Janse, J., Kojić, M., Stanković, S., Gavrilović, V., and Fira, Đ. 2015. Molecular assessment of genetic diversity of Xanthomonas arboricola pv. juglandis strains from Serbia by various DNA fingerprinting techniques. Eur. J. Plant Pathol. 141:133-145.

Janse, J. D. 2005. Phytobacteriology, Principles and Practice. CABI Publishing, Wallingford, UK.

Kaluzna, M., Pulawska, J., Waleron, M., and Sobiczewski, P. 2014. The genetic characterization of Xanthomonas arboricola pv. juglandis, the causal agent of walnut blight in Poland. Plant Pathol. 63:1404-1416.

Lelliott, R. A., and Stead, D. E. 1987. Methods for the diagnosis of bacterial diseases of plants. Methods in Plant Pathology. T. F. Preece, ed. Vol. 2. Blackwell Scientific Publications, Oxford, UK.

Louws, F. J., Fulbright, D. W., Stephens, C. T., and de Bruijn, F. J. 1994. Specific genomic fingerprints of phytopathogenic Xanthomonas and Pseudomonas pathovars and strains generated with repetitive sequences and PCR. Appl. Environ. Microbiol. 60:2286-2295.

Manulis, S., Valinsky, L., Lichter, A., and Gabriel, D. W. 1994. Sensitive and specific detection of Xanthomonas campestris pv. pelargonii with DNA primers and probes identified by random amplified polymorphic DNA analysis. Appl. Environ. Microbiol. 60:4094-4099.

Mirik, M., Unlu, S., and Aysan, Y. 2010. First report of Xanthomonas hortorum pv. pelargonii causing bacterial blight of geranium in Turkey. Plant Pathol. 59:403-404.

Nameth, S. T., Daughtrey, M. L., Moorman, G. W., and Sulzinski, M. A. 1999. Bacterial blight of geranium: A history of diagnostic challenges. Plant Dis. 83:204-212.
Schaad, N. W. 1988. A Laboratory Guide for Identification of Plant Pathogenic Bacteria. American Phytopathological Society, St. Paul, MN.

Schaad, N. W., Jones, J. B., and Chun, W. 2001. Laboratory Guide for Identification of Plant Pathogenic Bacteria, 3rd ed. American Phytopathological Society, St. Paul, MN.

Sulzinski, M. A., Moorman, G. W., Schlagnhaufer, B., and Romaine, C. P. 1995 Fingerprinting of Xanthomonas campestris pv. pelargonii and related pathovars using random-primed PCR. J. Phytopathol. 143:429-433.

Sulzinski, M. A., Moorman, G. W., Schlagnhaufer, B., and Romaine, C. P. 1996. Characteristics of a PCR-based assay for in planta detection of Xanthomonas campestris pv. pelargonii. J. Phytopathol. 144:393-398.

Tamura, K., Stecher, G., Peterson, D., Filipski, A., and Kumar, S. 2013. MEGA6: Molecular evolutionary genetics analysis version 6.0. Mol. Biol. Evol. 30: 2725-2729.

Tuinier, J. E., and Stephens, C. T. 1989. Use of serology to detect Xanthomonas campestris pv. pelargonii in aqueous extracts of geranium plants. Plant Dis. 73:875-878.

Vauterin, L., Hoste, B., Kersters, K., and Swings, J. 1995. Reclassification of Xanthomonas. Int. J. Syst. Bacteriol. 45:472-489.

Versalovic, J., Schneider, M., de Bruijn, F. J., and Lupski, J. R. 1994. Genomic fingerprinting of bacteria using repetitive sequence-based polymerase chain reaction. Methods Mol. Cell. Biol. 5:25-40.

Wainwright, S. H., and Nelson, P. E. 1972. Histopathology of Pelargonium species infected with Xanthomonas pelargonii. Phytopathology 62 1337-1347

Young, J. M., Park, D. C., Shearman, H. M., and Fargier, E. 2008. A multilocus sequence analysis of the genus Xanthomonas. Syst. Appl. Microbiol. 31: 366-377.

Zhang, S., Sairam, R. V., Grefer, D., Feasel, J., Ferencak, M., and Goldman, S. L. 2009. Resistance to Xanthomonas campestris pv. pelargonii in geranium and diagnosis of the bacterial blight using polymerase chain reaction. Arch. Phytopathol. Plant Prot. 42:1109-1117. 